Note

\section{Susceptibility of Bovine Lactoferrin to Plasmin and Chymosin}

\author{
Kei-ichi Shimazaki, Sachiyo Nagata \\ and Yung Choon YoO \\ Dairy Chemistry Research Laboratory, \\ Department of Bioindustrial Chemistry, \\ Division of Bioresource Chemistry, \\ Obihiro University of Agriculture \\ and Veterinary Medicine, \\ Obihiro, Hokkaido 080, Japan
}

Received August 9, 1990

Lactoferrin has been found in many secretions and in leukocytes. ${ }^{1)}$ To use bovine milk lactoferrin in food processing, food additives, feed supplement, and medical use, ${ }^{2)}$ it is necessary to understand the behavior of lactoferrin in bodies. The sensitivities of bovine lactoferrin to major digestive enzymes such as trypsin, chymotrypsin, and pepsin have been reported by many investigators. ${ }^{3-5}$ However, the effects of other proteolytic enzymes such as plasmin and chymosin on lactoferrin have not been studied. In this report, the susceptibilities of bovine lactoferrin to two proteolytic enzymes, chymosin, which is a milkclotting enzyme from calf stomach (abomasum) and plasmin, from serum, were studied in comparison with that to trypsin.

Lactoferrin isolated from bovine mature milk by the method of Law and Reiter ${ }^{6)}$ was used. The lyophilized sample was stored at $5^{\circ} \mathrm{C}$ till use. The iron content of the lactoferrin was $14.5 \mathrm{mg} / 100 \mathrm{~g}$ protein. Bovine pancreas trypsin (EC 3.4.21.4, Type XIII, TPCK treated), chymosin (EC 3.4.23.4), and plasmin (EC 3.4.21.7) from bovine and porcine plasma were products of Sigma Chem. Co., (St. Louis, MO, U.S.A.). Another chymosin was prepared chromatographically from calf stomach rennet (Chr. Hansen Laboratory, Copenhagen, Denmark) by the reported procedure. ${ }^{7)}$

Proteolysis of lactoferrin by trypsin was done in $0.05 \mathrm{M}$ Tris-HCl buffer, $\mathrm{pH} 7.8$, containing $0.02 \mathrm{M} \mathrm{CaCl}_{2}$. Chymosin digestion was done in $0.05 \mathrm{M}$ phosphate buffer, $\mathrm{pH}$ 6.3-6.5. For plasmin digestion, lactoferrin dissolved in $0.067 \mathrm{M}$ phosphate buffer, $\mathrm{pH} 7.4$, and plasmin dissolved in $0.05 \mathrm{M}$ Tris $0.02 \mathrm{M}$ lysine, containing $0.1 \mathrm{M} \mathrm{NaCl}$ and $0.001 \mathrm{~m}$ EDTA, $\mathrm{pH} 9.0^{8)}$ were mixed for reaction. All enzymatic reactions were done at $37^{\circ} \mathrm{C}$. To stop the reaction, buffer containing $1 \%$ sodium dodecyl sulfate (SDS) and 1\% 2-mercaptoethanol was added to the reaction mixture and heated at $100^{\circ} \mathrm{C}$ for $5 \mathrm{~min}$.

SDS-polyacrylamide gel electrophoresis was done using the PhastSystem with PhastGel homogeneous 12.5. Then protein bands were stained by Coomassie brilliant blue $\mathrm{R}$. A low molecular weight calibration kit was used for estimation of the molecular weight. The instrument, gels, and molecular weight standard kit were the products of Pharmacia AB (Uppsala, Sweden). Protein concentrations were measured by UV absorption at $280 \mathrm{~nm}$ using the extinction coefficient of 15.1 for lactoferrin, ${ }^{\text {9) }} 16.6$ for trypsin, ${ }^{91}$ and 15.3 for plasmin. ${ }^{107}$ For chymosin, the value of 14.3 at $278 \mathrm{~nm}^{9}$ was used.

As in Fig. 1, plasmin digestion was much less effective than control trypsin digestion ( $T$ in Fig. 1). When the digestion by plasmin was done with an enzyme-substrate ratio of $1 / 100$, no new bands were observed. Thus, an excess was used to digest lactoferrin. The degraded peptide bands with porcine plasmin were observed $20 \mathrm{hr}$ after the digestion, and the electrophoretic profile obtained was similar to that of the tryptic digest. On the other hand, the electrophoretic profile of the digest obtained by bovine plasmin showed that lactoferrin is partially digested. The molecular mass of main fragments obtained by porcine

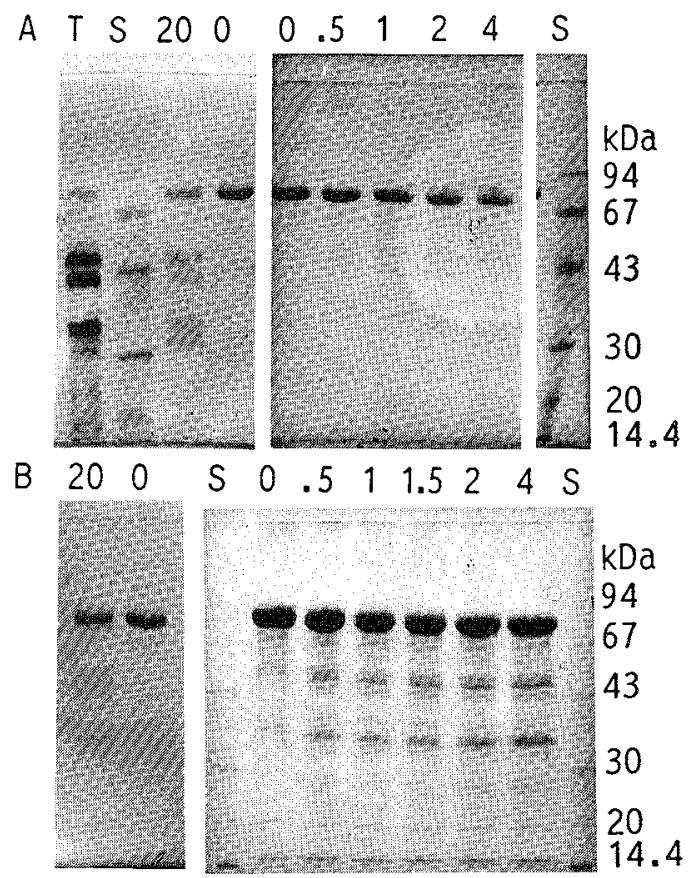

Fig. 1. SDS-Polyacrylamide Gel Electrophoretic Profiles of Bovine Lactoferrin Digested by Porcine Plasmin (A) and Bovine Plasmin (B).

PhastGel homogeneous 12.5, sample applicator 8/0.5 and PhastGel BlueR were used. $\mathbf{T}$ is the tryptic digestion of lactoferrin (for $1 \mathrm{hr}$, trypsin-lactoferrin ratio was $\mathrm{l}: \mathrm{100}$ ). The numbers indicate the reaction times in hours and $\mathbf{S}$ is the standard proteins for molecular weight calibration. Plasmin-lactoferrin ratio was $1: 10$. 
plasmin digestion (for $20 \mathrm{hr}$ ) were estimated to be 51,44 , 36 , and $32 \mathrm{kDa}$, and two major fragments obtained by bovine plasmin digestion (for $4 \mathrm{hr}$ ) were estimated to be 51 and $35 \mathrm{kDa}$.

Chymosin, both the commercial product and that purified in our laboratory, have no action on bovine lactoferrin (data not shown). This suggests the resistance of bovine lactoferrin to chymosin. This may help lactoferrin present in ingested colostrum reach the intestine without much breakdown in the abomasum, in spite of the lower lactoferrin concentration in bovine milk than in human milk. "Human lactoferrin was not digested by chymosin (data not shown), although chymosin is not found in the stomach of human newborns. In the human stomach, however, the proteolytic enzyme secreted is pepsin, which could digest lactoferrin more easily than other proteolytic enzymes, ${ }^{4,11)}$ though its action is pH-dependent. Thus, it is considered that the hydrolysis of lactoferrin may be minimal at the usual postprandial $\mathrm{pH}$ in the stomach ${ }^{11}$ ) and many investigators have considered the survival of human lactoferrin in spite of digestion in the gastric and gut lumen. ${ }^{1,11,12 \text {; }}$

Acknowledgments. This work was supported by a Grant of the Morinaga Houshikai (Tokyo). The authors thank Dr. H. Kuwayama in our college and Dr. I. Kiyosawa (Tamagawa University, Machida) for their helpful discussions and to Dr. M. Tomita and Dr. Y. Fukuwatari (Nutritional Science Laboratory, Morinaga Milk Co., Ltd., Zama) for supplying lactoferrin.

\section{References}

1) B. Reiter, "Developments in Dairy Chemistry -3, Lactose and Minor Constituents," ed. by P. F. Fox, Elsevier Applied Sci. Pub., London, 1985, pp. 281-336.

2) K. Shimazaki, Rakunoukagaku Shokuhin no Kenkyu, 38, A277 (1989) (in Japanese).

3) I. H. Brock, A. Piñeiro and F. Lampreave, Ann. Rech. Vet., 9, 287 (1978).

4) T. Suzuki, M. Nonaka, I. Kiyosawa and K. Ogasa, Eiyou to Shokuryo, 31, 395 (1978) (in Japanese).

5) R. D. Brines and J. H. Brock, Biochim. Biophys. Acta, 759, 229 (1983).

6) B. A. Law and B. Reiter, J. Dairy Res., 44, 595 (1977).

7) B. Foltmann, "Methods in Enzymology," Vol. 19, ed. by G. E. Perlmann and L. Lorand, Academic Press, New York, 1970, pp. 42I-436.

8) K. C. Robbins and L. Summaria, "Methods in Enzymology," Vol. 19, ed. by G. E. Perlmann and L. Lorand, Academic Press, New York, 1970, pp. 184-199.

9) "Handbook of Biochemistry and Molecular Biology, 3rd Ed., Proteins," Vol. II, ed. by G. D. Fasman, CRC Press Inc., Cleaveland, 1976.

10) L. Summaria, L. Arzadon, P. Bernabe and K. C. Robbins, J. Biol. Chem., 248, 6522 (1973).

11) J. R. Britton and O. Koldovský, Early Human Develop., 19, 127 (1989).

12) J. H. Brock, Arch. Dis. Child., 55, 417 (1980). 